\title{
STRUKTUR KOMUNITAS IKAN DI DANAU PALUI KABUPATEN BARITO SELATAN
}

\author{
(Structure Of Fish Community In Palui Lake Regency Of South Barito)
}

\author{
Ummi Suraya dan Aunurafik \\ Jurusan Perikanan Fakultas Pertanian Universitas Palangka Raya \\ Kampus UNPAR Tunjung Nyaho Palangkaraya \\ Email : ummisuraya1212@gmail.com
}

Article Submitted: 27-04-2020

Article Accepted: 14-09-2020

\begin{abstract}
This study aims to determine the existence of fish community structure in terms of diversity, uniformity, and dominance of fish species in Lake Palui. While the benefits of this research are to increase knowledge and skills about the structure of fish communities that live in these waters. Thus the results of this study can be used as basic information in research, monitoring, and management of the water environment. This research activity was carried out for 3 months, from September 2018 to December 2018 while the research location was carried out in Danau Palui, South Dusun District, South Barito Regency. The research method used was the installation of gill nets with the size of Mesh Size 1 inch, 2 inches, and 3 inches. As well as fish sampling 3 (three) times with an interval of once a month. From the results of the study obtained 6 families and have been identified as many as 10 species with a total number of 306 individuals, family Cyprinidae, Siluriade, Bagridae Belontidae, Silatade, Maconus macro nuts, and Anabantidae. The results of data analysis showed that the structure of fish communities in Lake Palui waters obtained diversity index $\left(\mathrm{H}^{\prime}\right)$ ranged between $(0.709-0.827)$ this value indicates that the level of diversity in Lake Palui waters is classified as low because it is less than 1 . The uniformity index (E) ranges between $(0.866-0.911)$ shows that the distribution of the number per type is almost the same because the uniformity index (E) is close to 1 . While the dominance index value (D) ranges between (0.178 - 0.211) (close to 0), this shows that Lake Palui waters do not exist in dominant fish species.
\end{abstract}

Keywords: Lake Palui, fish community structure

\section{PENDAHULUAN}

Provinsi Kalimantan Tengah memiliki luas wilayah $\pm 153.800 \mathrm{~km}^{2}$, yang memiliki potensi perairan umum daratan seluas \pm 2.290 .000 ha, luas perairan danau \pm 132.800 ha, jumlah danau \pm 690 buah, sungai 323.500 ha yang terdiri dari 11 sungai besar dan \pm 1.811 .500 ha rawa. Dari luas rawa yang terdapat di Kalimantan Tengah, sekitar 1.8 juta ha merupakan lahan rawa yang digunakan untuk usaha perikanan. Adanya perairan umum daratan yang begitu luas, Kalimantan Tengah memiliki potensi sumberdaya yang sangat besar untuk dapat dimanfaatkan khususnya dalam bidang perikanan (DKP, 2017).

Danau merupakan salah satu perairan umum yang cukup potensial untuk pengembangan sumberdaya perikanan. Salah satu danau yang dijadikan untuk menangkap ikan yaitu danau Palui. Danau ini merupakan danau yang terletak di Kecamatan Dusun Selatan, Kabupaten 
Barito Selatan dengan luas \pm 150 ha yang hanya dapat dilewati dengan jalur air menggunakan perahu motor diperlukan waktu \pm 30 menit melalui anak Sungai Barito (Anonim, 2017), .

Danau Palui adalah salah satu danau oxbow (oxbow lake) dengan bentuk tapal kuda (lunate). Sebagian besar sumber airnya berasal dari Sungai Barito, karena merupakan daerah limpasan banjir (flood plain lakes) (Anonim, 2017).

Perairan umum seperti danau merupakan salah satu sumberdaya perairan yang sangat penting, dimana pemanfaatan melalui usaha penangkapan ikan, guna memenuhi kebutuhan gizi dan peningkatan kesejahteraan manusia. Pemanfaatan perairan melalui usaha penangkapan ikan terus menerus dilakukan oleh masyarakat khususnya nelayan, tanpa menyadari terjadinya penurunan populasi ikan. Permasalahan tersebut dapat mempengaruhi dari beberapa sifat ekosistem dan struktur serta parameter biologi perairan yang secara langsung mempengaruhi komunitas suatu ikan.

Danau Palui menjadi satu perairan danau yang memiliki potensi sumberdaya perikanan yang baik untuk dikembangkan, dalam perairan tersebut terdapat berbagai spesies ikan. Danau ini merupakan penunjang perekonomian masyarakat sekitar karena menjadi tempat kegiatan penangkapan ikan (fishing ground). Perairan ini merupakan perairan yang tergenang dimana air yang masuk ke perairan melalui luapan air Sungai Barito. Mengingat pentingnya peranan Danau Palui sebagai potensi sumberdaya perikanan yang sebelumnya belum pernah diadakan penelitian didaerah tersebut, maka perlu dilakukannya penelitian tentang keberadaan komunitas ikan menggunakan alat tangkap jaring insang (Gill net).

Penelitian ini adalah untuk mengetahui data dan gambaran tentang kondisi sumberdaya perikanan dilihat dari struktur komunitas ikan yang meliputi keanekaragaman, keseragaman, dominasi jenis ikan yang dapat tertangkap dengan menggunakan jaring insang (Gill net) di Danau Palui. Sedangkan manfaat penelitian ini adalah untuk menambah pengetahuan dan keterampilan tentang struktur komunitas ikan yang hidup di perairan tersebut.

\section{METODE PENELITIAN}

\section{Waktu dan Tempat}

Penelitian ini dilaksanakan selama 3 bulan yaitu pada bulan September 2018 sampai dengan bulan Desember 2018, yang berlokasi di Danau Palui Kecamatan Dusun Selatan Kabupaten Barito Selatan.

\section{Metode Penelitian}

Metode yang digunakan dalam penelitian ini adalah survei atau observasi langsung ke lapangan (Nasir, 1988). Pemasangan alat tangkap untuk mendapatkan sampel ikan dilakukan secara "purpossive sampling". Di lokasi penelitian di tetapkan 3 (tiga) stasiun yang dianggap dapat mewakili perairan Danau Palui tersebut, yaitu :

Stasiun I : Mewakili bagian hulu dengan karakteristik perairan terbuka bagian pinggir danau bervegetasi merupakan tempat keluar masuknya ikan dan tempat pemasukan air ke Danau Pampait. Titik koordinat S $02^{\circ} 15{ }^{\prime} 32.4$ " E $114^{\circ} 03^{\prime} 52.1^{\prime \prime}$

Stasiun II : Mewakili bagian tengah danau perairan tertutup dengan karakteristik bervegetasi pada musim kemarau daerah ini tempat berkumpulnya ikan. Titik koordinat S $02^{\circ} 15^{\prime} 23.7^{\prime \prime}$ E 11404'19.2"

Stasiun III : Mewakili bagian hilir danau dengan karakteristik perairan terbuka bagian pinggir bervegetasi merupakan tempat keluarnya air dan tempat masuknya ikan. Titik 


\section{koordinat S $02^{\circ} 15^{\prime} 31.1 " \mathrm{E}$ $114^{\circ} 04^{\prime} 46.3^{\prime \prime}$}

\section{Penggambilan Sampel Ikan}

Penggambilan sampel ikan dilakukan dengan pemasangan alat tangkap jaring insang (Gill net) yang dipasang pada masing-masing stasiun yang mana setiap stasiun menggunakan 3 (tiga) buah alat tangkap jaring insang yang mempunyai ukuran mesh size yang berbeda, yaitu dengan ukuran 1 inchi berukuran $40 \times 1,5 \mathrm{~m}$, 2 inchi berukuran $40 \times 2,5 \mathrm{~m}$ dan 3 inchi berukuran 40 x $3 \mathrm{~m}$. Jaring insang ini dioperasikan dengan 1 (satu) kali pengangkatan yaitu dipasang pada pukul 08.00 Wib pagi hari dan diangkat padamalam hari pulul 20.00 WIB. Penggambilan sampel ikan dilaksanakan sebanyak 3 (tiga) kali dengan selang waktu sebulan sekali.

Setiap penggambilan sampel ikan, jumlah dan jenis ikan yang tertangkap dipisahkan serta dicatat per stasiun dimasukan kedalam ember yang berbeda untuk setiap stasiun pengamatan kemudian dimasukkan ke dalam boks styrofoam yang berisi es dan diawetkan dengan formalin $4 \%$ dan sampel ikan besar diawetkan dengan formalin $10 \%$ serta diidentifikasi.

\section{Analisis Data}

Data yang dikumpulkan yaitu data spesies dan jumlah individu populasi jenis. Data yang diperoleh disajikan dalam bentuk tabulasi kemudian data tersebut dianalisis dengan menggunakan berbagai indeks.

1. Keanekaragaman jenis ikan

$$
\mathrm{H}^{\prime}=-\sum \frac{\mathrm{ni}}{\mathrm{N}} \log \frac{\mathrm{ni}}{\mathrm{N}} \text { Indeks }
$$

keanekaragaman diuraikan untuk mengetahui keanekaragaman spesies yang ada dari suatu komunitas pada masingmasing stasiun pengamatan. Indeks keanekaragaman menggunakan indeks keanekaragaman Shannon Wiener dalam Soegianto (1994).

Dimana :

$\mathrm{H}^{\prime}=$ Indeks keragaman ni $=$ Jumlah Individu spesies ke-I

$\mathrm{N}=$ Jumlah total individu

Nilai atau kriteria keanekaragaman jenis adalah :

$\mathrm{H}^{\prime}<1=$ Keanekaragaman rendah

$\mathrm{H}^{\prime}=1<3=$ Keanekaragaman sedang

$\mathrm{H}^{\prime}>3=$ Keanekaragaman tinggi

2. Keseragaman jenis Ikan

Indeks keseragaman digunakan untuk mengetahui keseragaman spesies ikan yang ada pada masing-masing stasiun pengamatan. Indeks keseragaman menggunakan Evennes dalam Soegianto (1994).

$$
\mathrm{E}=\frac{\mathrm{H}^{\prime}}{\log \mathrm{S}}
$$

Dimana :

$\mathrm{E}=$ Indeks keseragaman

$\mathrm{H}^{\prime}=$ Indeks keanekaragaman

$\mathrm{S}=$ Jumlah spesies

Kriteria yang digunakan untuk mengetahui indeks keseragaman pada masing-masing stasiun pengamatan adalah sebagai berikut : Indeks keseragaman (E) berkisar antara $0-1$. Jika nilai $\mathrm{E}$ mendekati 1 berarti jumlah jenis organisme ikan dalam perairan banyak dengan jumlah individu perjenis hampir sama (seragam), jika nilai $\mathrm{E}$ mendekati 0 berarti jumlah jenis sedikit diikuti oleh jumlah individu perjenis tidak sama/terdapat perbedaan.

3. Dominasi Jenis Ikan

Indeks dominasi digunakan untuk mengetahui banyaknya individu dari suatu spesies dalam suatu komunitas pada masingmasing stasiun pengamatan. Indeks dominasi menggunakan indeks Simpson dalam Soegianto (1994).

$$
\mathrm{D}=\sum(\mathrm{ni} / \mathrm{N})
$$

Dimana :

$\mathrm{D}=$ Indeks dominasi

ni = Jumlah Individu Ke-I

$\mathrm{N}=$ Jumlah total individu 
Kriteria yang digunakan untuk mengetahui dominasi pada masing-masing stasiun pengamatan adalah sebagai berikut :

$\mathrm{D}=0$, berarti dominasi rendah

$\mathrm{D}=1$, berarti dominasi tinggi

4. Identifikasi Ikan

Ikan hasil tangkapan selama penelitian diidentifikasi dengan menggunakan metode Saanin (1984) dan Kotelat, (1993).

\section{HASIL DAN PEMBAHASAN}

\section{Kondisi Lingkungan Perairan}

Di danau Palui di temukan beberapa jenis tumbuhan air yang hidup di sekitar danau, antara lain jenis tumbuhan air yang mengapung bebas pada permukaan air, seperti : eceng gondok (Eichhornia crassipes mart) dan jenis tumbuhan yang hidup di daratan sepanjang Danau Palui seperti : karet dan rotan. Diharapkan dengan adanya tanaman di pinggiran danau akan mengurangi aliran permukaan dan erosi di sepanjang tepian danau, sehingga pendangkalan dan penimbunan lumpur pada danau dapat dicegah dan dikurangi.

Dilihat dari segi pemanfaaatannya, Danau Palui sampai sekarang lebih banyak dimanfaatkan untuk usaha penangkapan dari pada usaha budidaya ikan. Hal ini disebabkan para nelayan setempat masih mengandalkan hasil tangkapan untuk kebutuhan konsumsi masyarakat setempat.

\section{Jenis-jenis Ikan Yang Tertangkap}

Ikan yang tertangkap di Danau Palui dari hasil pengambilan sampel ikan tercatat ada 10 (sepuluh) spesies ikan yang tergolong dalam 6 (enam) famili dengan kelimpahan 306 (tiga ratus enam) individu. Untuk lebih jelasnya jenis-jenis ikan yang tertangkap selama proses pengambilan sampel di Danau Palui , dapat dilihat pada tabel 2.

Berdasarkan data di atas, terdapat 10 (sepuluh) spesies ikan yang berasal dari 6 famili. Dapat dilihat ikan yang paling dominan atau banyak tertangkap selama penelitian di Danau Palui yaitu ikan Menangin sebanyak 81 ekor, Seluang sebanyak 41 ekor, Banta sebanyak 49 ekor, Puhing sebanyak 55 ekor, Lais junggang sebanyak 41 ekor, Baung sebanyak 4 ekor, Sepat rawa sebanyak 5 ekor, Riu sebanyak sebanyak 2 ekor dan Betok sebanyak 1 ekor. Ikan yang paling dominan atau banyak tertangkap selama penelitian di Danau Palui yaitu ikan family Cyprinidae terutama spesies Thynichthys polylepisdd dengan jumlah relatif banyak dan yang paling sedikit ditemukan adalah spesies Anabas testudineus.

Tabel 2. Jenis - Jenis Ikan Yang Tertangkap Per Stasiun Pengamatan di Danau Palui.

\begin{tabular}{|c|c|c|c|c|c|c|c|}
\hline \multirow{2}{*}{ No } & \multirow{2}{*}{ Famili } & \multirow{2}{*}{ Nama Spesies } & \multirow{2}{*}{ Nama Lokal } & \multicolumn{3}{|c|}{$\begin{array}{c}\text { Stasiun } \\
\text { Pengamatan }\end{array}$} & \multirow{2}{*}{ Jumlah } \\
\hline & & & & I & II & III & \\
\hline 1 & \multirow[t]{5}{*}{ Cyprinidae } & Thynichthys polylepis & Menangin & 39 & 24 & 18 & 81 \\
\hline 2 & & Rasbora jacopsoni & Seluang & 16 & 15 & 10 & 41 \\
\hline 3 & & Osteochilus triporos & Banta & 23 & 12 & 14 & 49 \\
\hline 4 & & Cycloheilichthys apogon & Puhing & 17 & 17 & 21 & 55 \\
\hline 5 & & Osteochils melanoplenura & Kalabau & 9 & 10 & 8 & 27 \\
\hline 6 & Siluriade & Cyptopterus micronema & Lais Junggang & 13 & 26 & 2 & 41 \\
\hline 7 & Bagridae & Macrones nemurus & Baung & 3 & 1 & 0 & 4 \\
\hline 8 & Belontidae & Trichogaster trichopterus & Sepat Rawa & 5 & - & - & 5 \\
\hline 9 & Pangasidae & Pangasius macronema & Riu & 2 & - & - & 2 \\
\hline 10 & Anabantidae & Anabas testudineus & Betok & - & 1 & - & 1 \\
\hline \multicolumn{4}{|c|}{ Jumlah } & 127 & 106 & 73 & 306 \\
\hline
\end{tabular}

Dominasi ikan dari spesies Thynichthys polylepis di Danau Palui dikarenakan jenis ikan ini hidup bergerombol yang menandakan bahwa jenis ini hidup sangat toleran di danau Palui. Hal ini seiring dengan Wawan et al. ( 2013) dimana 
dijelaskan bahwa jenis ikan yang tergolong hidup secara bergerombol itu merupakan jenis ikan yang tegolong dalam divis sekunder dimana jenis ini sangat toleran terhadap salitas serta perubahan suatu perairan.
Kurangnya jumlah spesies yang ditemukan dikarenakan kurang optimalnya alat tangkap yang digunakan dan juga ketrbatasan waktu serta luasan areal yang dijadikan lokasi pengamatan.

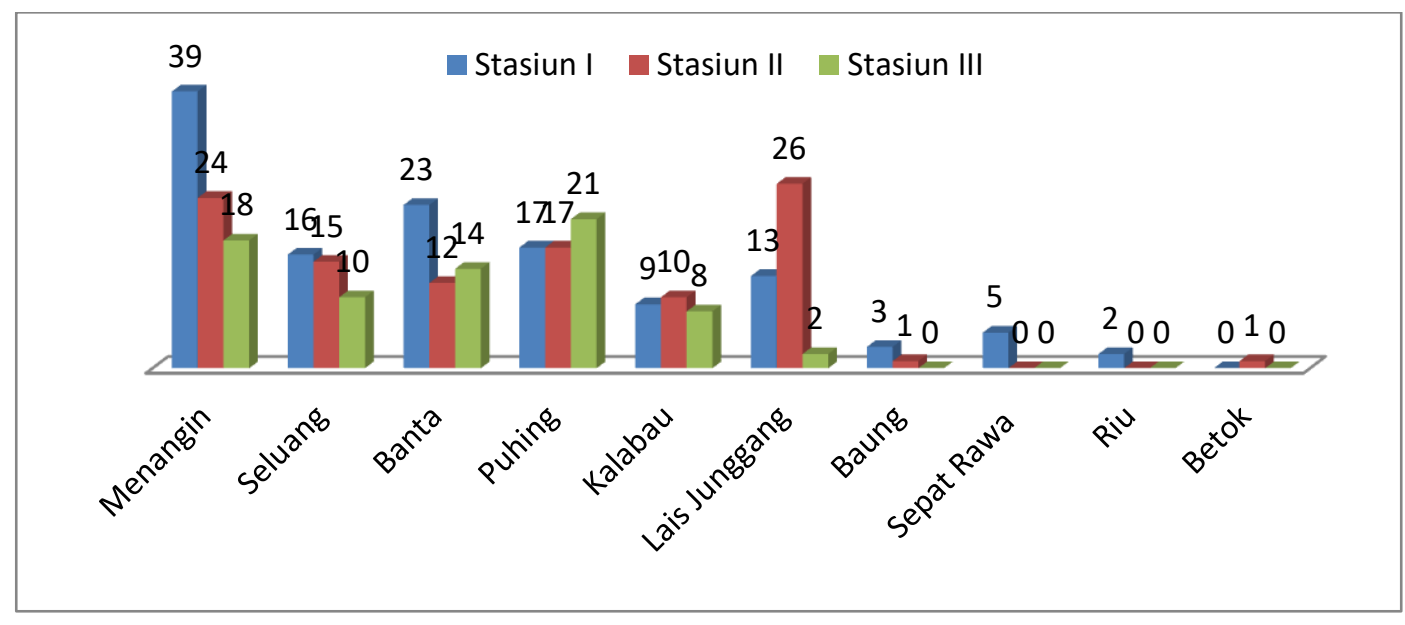

Gambar .1 Histogram Jumlah Keseluruhan Ikan Yang Tertangkap di Danau Palui

\section{Struktur Komunitas Ikan}

Hasil analisis terhadap contoh ikan yang tertangkap di perairan Danau Palui yaitu sebagai berikut.

Tabel 3. Hasil Perhitungan Indeks Keanekaragaman, Indeks Keseragaman dan Indeks Dominasi.

\begin{tabular}{cccc}
\hline $\begin{array}{c}\text { Stasiun } \\
\text { Pengamatan }\end{array}$ & Keanekaragaman $\left(\mathrm{H}^{\prime}\right)$ & $\begin{array}{c}\text { Keseragaman } \\
(\mathrm{E})\end{array}$ & $\begin{array}{c}\text { Dominasi } \\
(\mathrm{D})\end{array}$ \\
\hline I & 0,827 & 0,866 & 0,178 \\
II & 0,785 & 0,869 & 0,179 \\
III & 0,709 & 0,911 & 0,211 \\
\hline
\end{tabular}

\section{Keanekaragaman Jenis Ikan}

Berdasarkan analisis indeks keanekaragaman $\left(\mathrm{H}^{\prime}\right)$ pada stasiun I diperoleh hasil 0,827 bila dilihat dari segi segi kriteria keanekaragaman, maka nilai keanekaragaman pada stasiun I tergolong rendah karena nilainya kurang dari satu. Hasil analisis indeks keanekaragaman $\left(\mathrm{H}^{\prime}\right)$ pada stasiun II diperoleh hasil 0,785 angka ini menunjkan tingkat keanekaragaman pada perairan tersebut rendah, bila dibandingkan dengan stasiun I keanekaragaman di stasiun II lebih rendah. Pada stasiun III diperoleh hasil analisis indeks keanekaragaman $\left(\mathrm{H}^{\prime}\right)$ yaitu : 0,709 hasil ini lebih rendah dari stasiun I dan II hal ini disebabkan oleh stasiun III sebagai pemasukan dan pengeluaran air (in let dan out let) banyak dipasang alat tangkap selambau sehingga diasumsikan ikan yang hendak bermigrasi dari sungai ke danau dan sebaliknya terjebak ke dalam selambau. Berdasarkan klasifikasi nilai indeks keanekaragaman, maka keanekaragaman ikan pada semua stasiun tergolong rendah, hal ini sesuai dengan Kreb (1989) dalam Wawan et al. (2013) bahwa kisaran indeks keanekaragaman 
menurut Shannon-Wiener yaitu $\mathrm{H}<1$ maka keanekaragaman rendah.

\section{Keseragaman Jenis Ikan}

Analisis indeks keseragaman (E) pada stasiun I diperoleh hasil 0,866 nilai ini menunjukan bahwa penyebaran jumlah jenis per jenis hampir sama karena indeks keseragamannya mendekati I. Indeks keseragaman (E) pada stasiun II adalah 0,869 nilai ini menunjukan bahwa penyebaran spesies dalam suatu komunitas hampir sama, indeks keseragaman pada stasiun II lebih tinggi dari stasiun I. Indeks keseragaman (E) pada stasiun III diperoleh 0,911 nilai ini lebih tinggi dibandingkan stasiun I dan stasiun II. Berdasarkan klasifikasi nilai indeks keseragaman yang diperoleh pada semua stasiun menunjukakan penyebaran ikan tersebar secara merata dan tidak jauh berbeda. Hal ini sesuai dengan Kerbs (1978) dalam U. Suraya et al. (2015) bahwa nilai indeks keseragaman apabila $\mathrm{E}=0$, maka kemerataan antara spesies rendah, artinya kekayaan individu yang dimiliki masingmasing spesies sangat jauh berbeda, begitu juga sebaliknya apabila nilai $\mathrm{E}$ mendekati nilai satu maka penyebaraannya akan merata.

\section{Dominasi Jenis Ikan}

Hasil analisis indeks dominasi (D) pada stasiun I diperoleh 0,178 nilai ini menunjukan bahwa dominasi di Danau Palui rendah karena nilainya kurang dari satu. Pada stasiun I indeks dominasi lebih rendah dari stasiun II dan stasiun III hal ini disebabkan ada kemungkinan banyaknya penggunaan alat tangkap selambau pada daerah hilir sehingga ikan banyak yang hendak masuk ke danau terjebak kedalam selambau. Indeks dominasi (D) di stasiun II diperoleh 0,179 nilai ini lebih tinggi dibandingkan indeks dominasi pada stasiun I. Indeks dominasi diperoleh hasil 0,211 angka ini menunjukan bahwa dominasi ikan di perairan tersebut rendah. Menurut Hal ini menunjukan bahwa nilai indeks tersebut dominasi ikan nya dalam kategori rendah, hal ini didasarkan pada nilai kategori indeks dominansi, dimana nilai indeks dominansi berkisar antara 0-1; indeks 1 menunjukan dominansi oleh satu jenis spesies sangat tinggi (hanya terdapat satu jenis pada satu stasiun). Sedangkan indeks 0 menunjukan bahwa diantara jenis-jenis yang ditemukan tidak ada yang dominansi, hal ini terlihat dari hasil tangkapan dimana pada setiap stasiun ditemukan 2 sampai 6 jenis. . Hal ini terjadi karena pola penyebaran jenis ikan yang terjadi merata atau seragam di setiap stasiun. Sesuai dengan pernyataan Odum (1993) dalam Kiki et al. (2018) bahwa pola penyebaran yang seragam terjadi karena adanya persaingan individu sehingga mendorong pembagian ruang secara merata.

Struktur komunitas ikan di perairan Danau Palui dilihat dari indeks keanekaragaman (H') dan indeks keseragaman (E) tergolong sedang dan rendah jenis ikan dominan. Hal ini dapat diasumsikan bahwa di perairan Danau Palui para nelayan setempat sering melakukan penangkapan dengan menggunakan alat tanggap selambau (Seine net) yang dapat menyebabkan spesies ikan berkurang sehingga cenderung mempengaruhi struktur komunitas ikan yang ada di danau tersebut, hal ini seiring dengan $U$, Suraya dan Haryuni. (2013) bahwa alat tangkap selambau dapat membahayakan kelestarian sumberdaya perikanan terutama untuk jenis ikan. Oleh karena itu diharapkan untuk para nelayan agar memperhatikan ukuran mata jaring selambau supaya struktur komunitas ikan di Danau Palui tetap terjaga.

\section{KESIMPULAN}

1. Ikan yang tertangkap di perairan Danau Palui terdapat 10 spesies yang tergolong dalam 6 famili dengan kelimpahan 306 individu. Dan diperoleh indeks keanekaragaman (H') berkisar antara $(0,709$ - 0,827) nilai ini menunjukan 
bahwa tingkat keanekaragaman di perairan Danau Palui tergolong rendah. Indeks keseragaman (E) berkisar antara (0,866 - 0,911) ini menunjukan bahwa penyebaran jumlah per jenis hampir sama karena indeks keseragaman (E) mendekati 1. Sedangkan nilai indeks dominasi (D) berkisar antara $(0,178-$ 0,211) (mendekati 0), ini menunjukan bahwa diperairan Danau Palui tidak ada jenis ikan yang dominan.

2. Perairan di Danau Palui bila ditinjau dari struktur komunitasnya yang dilihat dari hasil perhitungan berbagai indeks, maka tingkat kesuburanya cukup baik, karena nilai indeks keanekaragaman $\left(\mathrm{H}^{\prime}\right)$ mendekati mendekati 1 dan indeks keseragaman (E) mendekati satu (tergolong sedang) serta, tidak ada jenis ikan yang menguasai wilayah Danau Palui.

\section{DAFTAR PUSTAKA}

Anonim, 2017. Laporan Tahunan Dinas Perikanan Buntok. Kabupaten Barito Selatan.

Dinas Kelautan dan Perikanan (DKP). 2017. Laporan Tahunan 2016. Dinas Kelautan dan Perikanan Provinsi Kalimantan Tengah. Palangka Raya.

Kiki Wulandari, Asriyana dan Alili. 2018. Struktur komunitas ikan di perairan Rawa Aopa Kecamatan Angata Kabupaten Konawe Selatan Provinsi Sulawesi Tenggara. Jurnal Manajemen Sumber Daya Perairan, 3(1): 75-81.
Kottelat, M. A. T., Whitten, S. N,. Kartika dan S. Wijoatmojo, 1993. Freshwater Fishery of Western Indonesia and Sulawesi. Perplus Edition Ltd. Jakarta.

Krebs, C. J. 1978. Ecology The Wxperimental Analysis of Distribution And Abundance. Harper And Row Publication. New York.

Nasir, M., 1988, Metodologi Penelitian. Ghalia Indonesia. Jakarta.

Saanin, H. 1984. Taksonomi dan Kunci Identifikasi Ikan I dan II. Bina Cipta Bogor.

Soegianto, A. 1994. Ekologi Kuantitatif, Metode Analisis Populasi dan Komunitas. Usaha Nasional Surabaya.

Ummi Suraya dan Haryuni. 2013. Evaluasi Perikanan Tangkap di Sungai Rungan Kalimantan Tengah. Jurnal Ilmu Hewani Tropika. Vol. 2 Edisi 2.

Ummi Suraya, Aunurafik dan Fahrizal. 2015. Struktur Komunitas Ikan Yang Tertangkap Di Danau Pampait. Jurnal Of tropical Fisheries. . Vol. 11 Edisi 1

Wawan Hermanto, Siti Nursinar dan Mulis. 2013. Struktur Komunitas Ikan Di Perairan Danau Limboto Desa Pentadio Kecamatan Telaga Biru Kabupaten Gorontalo. Jurnal Ilmu Perikanan dan kelautan. Vol. 1 No. 3. 